\title{
Impact Analysis of ICT based Educational Intervention on Change in Consumption of Junk Food Among School Going Children in Jaipur: A Vis a Vis Study

\author{
Sakshi Mehta, Swati Vyas
}

\begin{abstract}
Introduction and Objectives of Research Study: World data revealed the facts that twenty-first-century school-going children are more inclined towards the consumption of junk food especially during the COVID 19 pandemic period and this habit of consuming junk food is recognized as a serious health problem around the globe. Thus in this backdrop, the present research framework aims to assess the effectiveness of an ICT based educational intervention program for school going children in Jaipur Metropolitan City, India to reduce junk food consumption habits. Research Methodology: In the present research study data was collected with the help of a simple random sampling technique from $n=200$, school-going children of study area Jaipur. Primary data collection tool- a self-developed structured questionnaire was used in the present study. Data was collected in a phased manner i.e. Pre-test before intervention study and post-test after the ICT based interactive study. For statistical analysis, a multiple linear regression model and a paired t-test were used to assess the effectiveness of ICT based educational intervention programs in the present research study. Findings and Conclusion: Findings obtained from the present study concluded that among school children of Jaipur the behavioural intention of junk food consumption was different in pretest and posttest [4.98 \pm 1.6 and $6.84 \pm 1.2]$. The present research study concludes that the ICT based intervention program developed by the research scholar has been proved as an effective education program for changing the intentions of school-going children and also prevent them from making the habit of consuming junk food which was found statistically significant at the p-value $<0.05$. It was also found from the study that, the behavioural intention of junk food consumption, the attitude of school-going children towards junk food consumption, and perceived behavioural control toward junk food were statistically significant as the obtained p-value was $<0.05$. Implications of the study: In a nutshell, it can be postulated from the present research study that ICT based intervention program has a significant positive influence on the perceived behaviour without a control group of school-going children in the study area Jaipur and the same findings can be used unanimously in other study conditions around the globe.
\end{abstract}

Keywords: ICT, Intervention, Junk Foods, Obesity, School, Jaipur, SPSS.

Manuscript received on October 20, 2021.

Revised Manuscript received on November 21, 2021.

Manuscript published on November 30, 2021.

* Correspondence Author

Sakshi Mehta*, Research Scholar, Department of Home Science (Foods \& Nutrition), IIS (Deemed to be a University), Gurukul Marg, SFS, Mansarovar, Jaipur (Rajasthan), India. E-mail: sakshimehtaresearcher@gmail.com

Dr. Swati Vyas, Associate Professor, Department of Home Science (Foods \& Nutrition), IIS (Deemed to be a University), Gurukul Marg, SFS, Mansarovar, Jaipur (Rajasthan), India. E-mail: swativramani@gmail.com

(C) The Authors. Published by Blue Eyes Intelligence Engineering and Sciences Publication (BEIESP). This is an open access article under the CC BY-NC-ND license (http://creativecommons.org/licenses/by-nc-nd/4.0/)

Published By:

Blue Eyes Intelligence Engineering and Sciences Publication (BEIESP)

(C) Copyright: All rights reserved.

\section{INTRODUCTION}

In general terms, food is usually fast food that contains low fibre and nutrients but high fat, saturated fat, sodium are known as Junk food. (Boylan S. et. al., 2017). Varied researchers around the globe have scientifically claimed that these junk food have negative or ill effects on the overall nutritional status, health and cognitive development of school-going children. (Nazari A. et. al., 2016 and Sahoo K., et.al., 2015) World data revealed the fact that twentyfirst-century school-going children are more inclined towards the consumption of junk food especially during the COVID 19 pandemic period. (Niemeier H. M. et. al., 2006 and Nixon $\mathrm{H}$ et. al. 2011) Factors that contribute to more consumption of junk food among school children are good quality taste, simple ease of use, reasonably priced price, choice, \& flavour. (Shah T. et. al. 2014) This habit of consuming junk and fast food is worldwide leading to the danger of fatness \& cause public health problems especially among school-age children i.e 10 to 12 years school students. (Kar S. et. al., 2018)

Data obtained from WHO Nutrition report (2020) proclaims that 46 million children around the globe are victims of obesity or related health disease because of consuming Junk and fast food. (Rayner G. et. al., 2020) The ill effect of Junk food is through the globe but unfortunately developed countries have more cases than undeveloped countries and in developed countries like the USA or India the instances of more consumption of fast food are found considerably senior in urban school-going children than in rural school students. This trend can be an impact of liberalization of deal \& overseas asset rule on foodstuff \& drink crop in countries such as India. (Thow A. M. et. al., 2019) Thus the researcher found a significant change in consumption of food with low nutritional value has been the main cause of obesity among school-going children. (Popkin B. M. et. al., 2008) This insight the facts that ICT based intervention strategies should be developed specifically for school going children which can reduce the use of fast food and highlights the pros \& cons of eating healthy food. 


\begin{tabular}{|c|c|}
\hline Phases of the study & $\begin{array}{l}\text { The current learn be conduct in three phase. } \\
\text { First phase or Pre Test phase- Collection of baseline in order of fast food utilization via respondents under study } \\
\text { (n=200) school going students. } \\
\text { The second phase or Intervention Phase: } 3 \text { Months ( } 20 \text { hours) based on PPT, Videos, Posters, Lectures etc from } \\
\text { January } 2020 \text { to April } 2020 \text { with applied ethical permission from School authorities. } \\
\text { Third Phase or Post-test Phase: The intervention package (ICT based interactive lecture, videos, ppt etc) intended } \\
\text { for prevent the use of fast food to school going children were known in the direction of the similar participant in a } \\
\text { alike set of pretest throughout train hours and data collected after Intervention. }\end{array}$ \\
\hline $\begin{array}{l}\text { Analytical tools For Pilot } \\
\text { Study }\end{array}$ & Cronbach's alpha intended for dependability \& Kaiser Meyer's Rank Test for Variability \\
\hline $\begin{array}{l}\text { Statistical Analysis for } \\
\text { hypothesis testing }\end{array}$ & Multivariate ANOVA, Student paired “t” examination \& Multiple regression psychoanalysis. \\
\hline
\end{tabular}

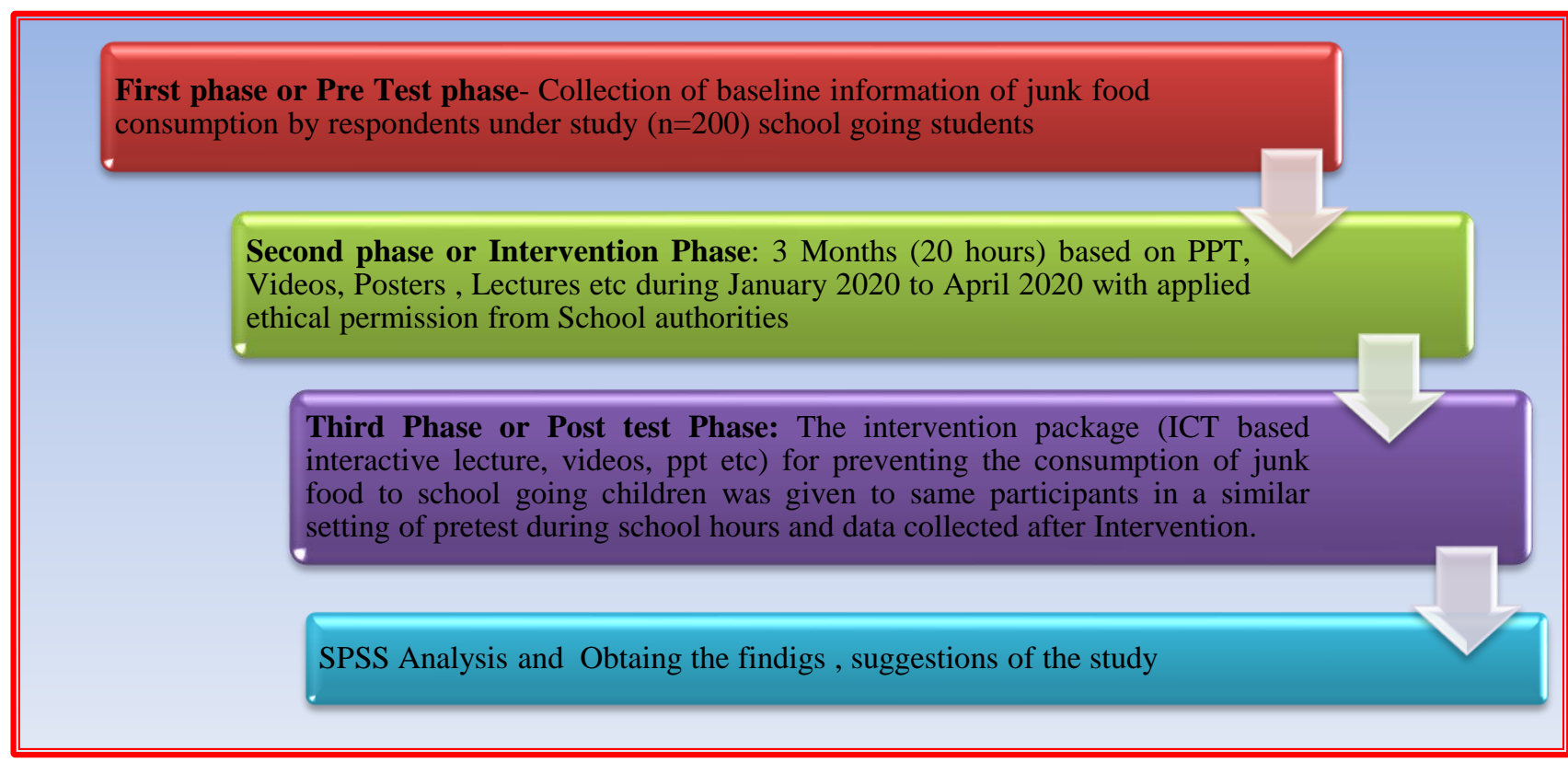

Figure 1. Research Flow Chart

Source: Researcher's Illustration

\section{RESULTS AND DISCUSSION}

\subsection{Pilot Study results:}

"It was found that Cronbach's alpha was $0.78,0.79,0.83$, and 0.82 for behaviour intention, attitude, subjective norm, and perceived behaviour, respectively." "Then pretesting was conducted on $10 \%$ of the total sample size in a similar setting but different school. Necessary changes were corrected accordingly after the pretesting of the tools." Figure 1 reflect the addition of school-going children and schools for this study.

\subsection{Demographic characters of School going Children under study.}

"As stated earlier $\mathrm{n}=200$ school going children of four private schools of Jaipur, the data for the present study was collected with a varied set of demographic characters" Table 1 shows the socio-demographic characteristics of respondent's i.e. school-going children. The majority of the respondents were from the middle school age group i.e. of Class $8^{\text {th }}(59 \%)$, were male students (63\%), and were Hindu (58\%). However, the preponderance of their father \& mother be graduates in qualification.

Table 1: Demographic characteristics of Selected School Going Children.

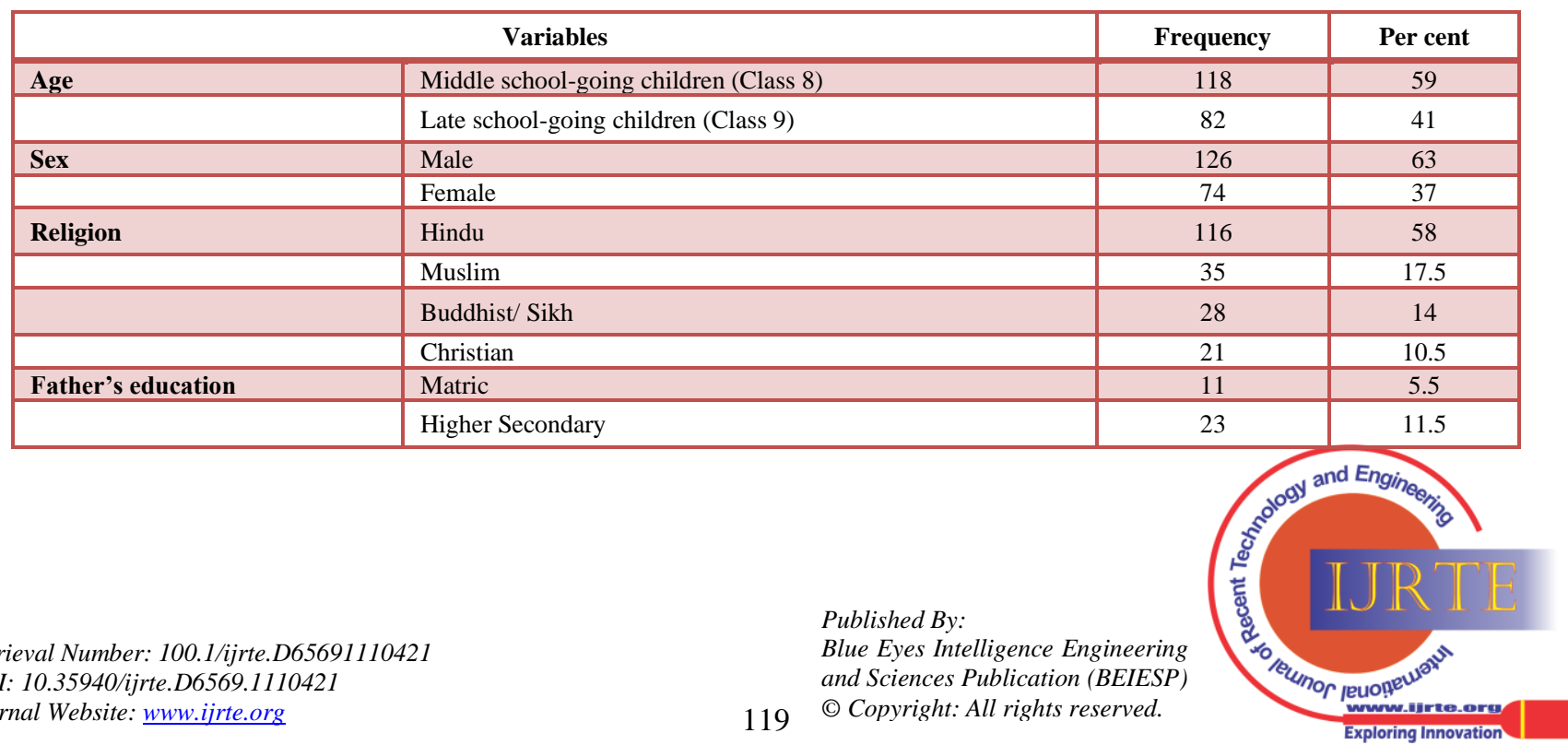


Impact Analysis of ICT based Educational Intervention on Change in Consumption of Junk Food Among School Going Children in Jaipur: A Vis a Vis Study

\begin{tabular}{|l|l|c|c|}
\hline & Graduate & 30 & 15 \\
\hline & Post Graduate & 82 & 41 \\
\hline & Doctorate/ Technical Qualification & 54 & 27 \\
\hline Mother's education & Matric & 22 & 11 \\
\hline & Higher Secondary & 34 & 17 \\
\hline & Graduate & 45 & 22.5 \\
\hline & Post Graduate & 68 & 34 \\
\hline & Doctorate/ Technical Qualification & 31 & 15.5 \\
\hline
\end{tabular}
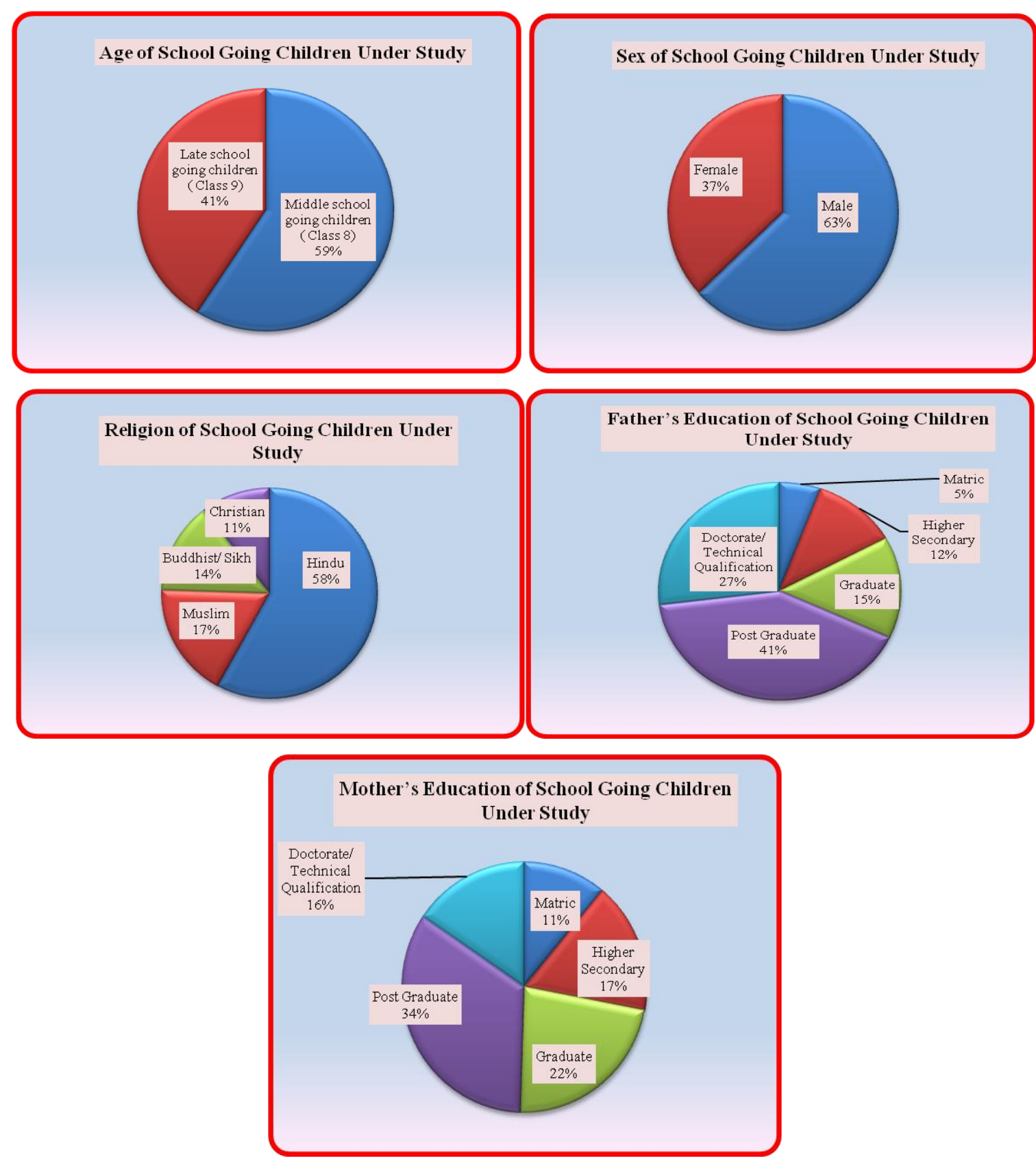

\section{Graph 1: Demographic characteristics of Selected School Going Children.}

\subsection{Pre-test and Post-test results of Meaning to Fast Food Use.}

In the present research, study school going students of Jaipur show a statistically important disparity in intention within stipulations of their meaning in the direction of consume $(P<0.0001) \&$ diagram to consume fast food in excess of the after that week $(P<0.0001)$ as exposed in Table 2 . The regular attain of behavioural meaning in the direction of fast food use throughout the pretest was $4.98 \pm 1.6$, which be distorted before the interference $6.84 \pm 1.2$.

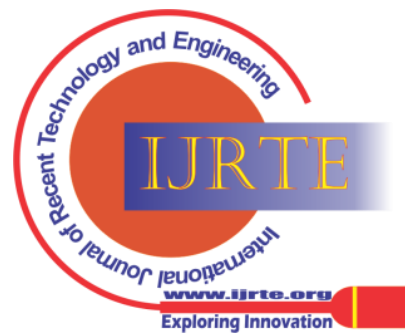


Results of the present study proclaimed that before the ICT based intervention, $52.23 \%$ of student have a far above the ground meaning in the direction of eat fast food in excess of the after that week which was decreased to $12.36 \%$ following the ICT based educational interference. The consequence of balancing $t$-tests show a statistically important dissimilarity inside behavioural meaning toward fast food use following the interference $(P<0.0001)$ as shown in Table 3.

Table 2: Intention toward junk food consumption in Pre and Post-test (ICT based Intervention)

\begin{tabular}{|c|c|c|c|c|}
\hline Statements & $\begin{array}{c}\text { Pretest } \\
\text { Mean } \pm \text { SD }\end{array}$ & $P$-value & $\begin{array}{c}\text { Posttest } \\
\text { Mean } \pm \text { SD }\end{array}$ & $P$-value \\
\hline \multicolumn{5}{|c|}{ Attitude toward junk food } \\
\hline I like the taste of junk food & $3.40 \pm 0.90$ & $<0.0001$ & $4.60 \pm 0.69$ & $<0.0001$ \\
\hline Satisfaction after eating junk food & $3.19 \pm 0.68$ & $<0.0001$ & $4.23 \pm 0.56$ & $<0.0001$ \\
\hline Junk food is good for health & $3.85 \pm 0.59$ & $<0.0001$ & $4.95 \pm 0.38$ & $<0.0001$ \\
\hline Junk food increases the weight & $3.56 \pm 0.78$ & $<0.0001$ & $3.98 \pm 0.67$ & $<0.0001$ \\
\hline It is convenient to prepare junk food & $3.67 \pm 0.88$ & $<0.0001$ & $4.12 \pm 0.62$ & $<0.0001$ \\
\hline \multicolumn{5}{|c|}{ Subjective norm toward junk food } \\
\hline Parents' approval for junk food & $3.98 \pm 0.32$ & $<0.0001$ & $4.92 \pm 0.36$ & $<0.0001$ \\
\hline Teachers' approval for junk food & $4.95 \pm 0.48$ & $<0.0001$ & $4.98 \pm 0.42$ & $<0.0001$ \\
\hline Friends' approval for junk food & $3.22 \pm 0.86$ & $<0.0001$ & $4.33 \pm 0.69$ & $<0.0001$ \\
\hline Siblings' approval for junk food & $3.38 \pm 0.80$ & $<0.0001$ & $4.38 \pm 0.70$ & $<0.0001$ \\
\hline \multicolumn{5}{|c|}{ Perceived behavioural control for junk food } \\
\hline $\begin{array}{l}\text { Advertisement influences me to eat junk } \\
\text { food }\end{array}$ & $3.63 \pm 0.65$ & $<0.0001$ & $4.53 \pm 0.64$ & $<0.0001$ \\
\hline Price influences me to eat junk food & $3.65 \pm 0.61$ & $<0.0001$ & $3.90 \pm 0.60$ & $<0.0001$ \\
\hline Limited time influences me to eat junk food & $3.56 \pm 0.71$ & $<0.0001$ & $4.31 \pm 0.72$ & $<0.0001$ \\
\hline $\begin{array}{l}\text { Easy accessibility of junk food in school } \\
\text { influences me to eat junk food }\end{array}$ & $3.72 \pm 0.77$ & $<0.0001$ & $4.35 \pm 0.82$ & $<0.0001$ \\
\hline \multicolumn{5}{|l|}{ Behaviouralintention toward junk food } \\
\hline I intend to eat junk food over the next week & $3.85 \pm 0.88$ & $<0.0001$ & $4.95 \pm 0.28$ & $<0.0001$ \\
\hline I plan to eat junk food over the next week & $3.79 \pm 0.80$ & $<0.0001$ & $4.99 \pm 0.19$ & $<0.0001$ \\
\hline
\end{tabular}

The result of balancing $t$-tests show a statistically important dissimilarity inside outlook to fast food expenditure subsequent to the interference $(<0.0001)$ as exposed inside Table 3. Thus as the P-value is highly significant it is found that null hypothesis $\mathbf{H}_{0}$ : "There is no significant effect of an ICT based educational intervention program in reducing Junk Food eating habits among school-going children in Jaipur" is Rejected and Alternate Hypothesis $\mathbf{H}_{1}$ : "There is no significant effect of an ICT based educational intervention program in reducing Junk Food eating habits among school-going children in Jaipur" is Accepted and Proved.

Table 3: Level of construct before and after intervention

\begin{tabular}{|c|c|c|c|c|c|}
\hline & Pretest $n(\%)$ & $\begin{array}{c}\text { Construct of TPB } \\
\text { Posttest } \boldsymbol{n}(\%)\end{array}$ & $\begin{array}{c}\text { Pre-t-test } \\
\text { Mean CSD }\end{array}$ & $\begin{array}{c}\text { Post- } t \text {-test } \\
\text { Mean } \pm \text { SD }\end{array}$ & $P$-value \\
\hline Attitude & & & $11.9 \pm 1.5$ & $16.3 \pm 1.6$ & $<0.0001$ \\
\hline Positive ( $\leq$ mean $)$ & $79(28.8 \%)$ & $142(51.8 \%)$ & & & \\
\hline Negative (>mean) & $195(71.2 \%)$ & $132(48.2 \%)$ & & & \\
\hline Subjective norm & & & $11.1 \pm 1.3$ & $14.3 \pm 1.4$ & $<0.0001$ \\
\hline Positive ( $\leq$ mean $)$ & $146(53.3 \%)$ & $181(66.1 \%)$ & & & \\
\hline Negative (>mean) & $128(46.7 \%)$ & $93(33.9 \%)$ & & & \\
\hline Perceived behavioural control & & & $9.9 \pm 1.0$ & $12.76 \pm 1.5$ & $<0.0001$ \\
\hline Positive $(\leq$ mean $)$ & $105(38.3 \%)$ & $142(51.8 \%)$ & & & \\
\hline Negative (>mean) & $169(61.7 \%)$ & $132(48.2 \%)$ & & & \\
\hline Behavioural intention & & & $4.98 \pm 1.6$ & $7.96 \pm .3$ & $<0.0001$ \\
\hline High ( $\leq$ mean $)$ & $182(66.4 \%)$ & $5(1.8 \%)$ & & & \\
\hline Low (>mean) & $92(33.6 \%)$ & $269(98.2 \%)$ & & & \\
\hline
\end{tabular}




\section{Impact Analysis of ICT based Educational Intervention on Change in Consumption of Junk Food Among School Going Children in Jaipur: A Vis a Vis Study}

Junk food is commonly eaten fast food or unhealthy leading meals in India, mainly with children of school age group around 11 to 13 years old and enhanced significantly during COVID19 pandemic period. The present study revealed that 94\% of school-going children under study eat Junk fast food. Consequently it is important in the direction of keep in mind how fast food desire be developing several schoolgoing children. "Therefore, this takes a look highlights the effectiveness of ICT based instructional intervention by conduct, \& behavioural goal towards fast food for several school-going children by the use of more than one linear weakening replica \& balancing t-test." "Results of the present study revealed that $85 \%$ of school-going children had fed on junk meals even as they were during intervention programme days." "The positive outcome of the effect was that majority of students who is school-going children under the present study have significantly reduced the consumption of junk food after ICT based intervention."

"Different studies carried out around the globe recommended that if the human beings acquired the information as of some basis of media/methods, then their purpose distorted into modified through physical condition schooling sports \& for that reason decreased the intake of junk food." (Pour-Abdollahi P. et. al., 2004 and Khalaj M. et. al. 2006) Consequently, students turn into much fewer tending in the direction of consume fast food in the container wherein they've distorted attitude closer to fast meals, \& their intention, otherwise pressure resting on them, toward apply fast meals are near to the ground. As a result, school-going children wonderful attitude be supposed to be bolstered inside do thru instructional interventions.

"Moreover, the denote rating of behavioural meaning for decreasing fast food intake becomes accelerated subsequent to the interference." "The denote rating of behavioural purpose at some stage in pretest became 8.2 whilst 11.9 throughout posttest." An add to inside the terrible approach in the direction of the fast meals intake has sensibly unspecified so as to present may be a growth inside the degree of information on top of fast food which help in the direction of boom the extent of consciousness \& saves you the excessive use of fast food. "Alike answer of our test be coordinated with some additional study which show so as to teaching be the important thing plan in the direction of fetch effective modifications in the direction of junk food consumption. Further, after converting their recognition stage, the general mean rating become found as 3.93 in pretest, while it becomes 5.34 in the posttest" "As a result, it be establish so as to instructive interference have a main position inside prevent the use of fast food." "These strategy do something in the direction of add to the constructive thoughts feel through school-going children \& show the way in the direction of rising the optimistic result of physical condition \& growth." Therefore this learn indicate so as to fast food use was mainly affected through the ICT based teaching interventional wrap up \&, so, the educate establishment \& administration be supposed to disburse additional notice to fast food \& give wanted letters next to the expenditure of fast food inside school. means of the variables of mindset, slanted norm, apparent

\section{CONCLUSIONS}

This learn show the efficiency of an ICT based instructive interference agenda in the middle of the school-going children in Jaipur. It be establish so as to the ICT based interactive technique is an effectual method intended for altering the meaning in the direction of eat fast food among school-going children under study. "Therefore, the instructive interference plan is effectual in favor of altering the student's outlook, prejudiced standard, \& insight behaviour in the direction of the use of fast food." Thus, it be optional so as to alike study call for toward be perform in additional community \& districts, on the local \& nationwide level in India.

1. Limitations of the Study: Firstly, the learn listening carefully merely on the school-age student as of chosen schools; we do not take in other student unpaid in the direction of the unavailability of occasion. Secondly, a researcher was not able to explore the behaviour of fast food in the midst of the school-going children outstanding on the way to the petite epoch. Consequently, it can not be alive potential to assess the efficiency of interference on behalf of prevent the use of fast food.

2. Data Availability: Data will be provided upon reasonable request from the corresponding author.

3. Conflicts of Interest: The authors declare that there are no conflicts of interest regarding the publication of this paper.

\section{REFERENCES}

1. Adversity I. F., (2003) "Malnutrition at age 3 years and lower cognitive ability at age 11 years," Archives of Pediatrics and Adolescent Medicine, vol. 157, no. 6, pp. 593-600.

2. Aryal R. K. M. K. K., Chalise B., Mehata S., and Sapkota F., (2014) Adolescent Nutrition Survey in India, NHRC, New Delhi, India.

3. Boylan S., Hardy L. L., Drayton B. A., Grunseit A., and Mihrshahi S., (2017) "Assessing junk food consumption among Australian children trends and associated characteristics from a cross-sectional study," BMC Public Health, vol. 17, no. 1, p. 299.

4. Bremer A. A. and Lustig R. H., (2012) "Effects of sugar-sweetened beverages on children," Pediatric Annals, vol. 41, no. 1, pp. 26-30.

5. Gomez-Pinilla F., (2008) "Brain foods: the effects of nutrients on brain function," Nature Reviews Neuroscience, vol. 9, no. 7, pp. 568578.

6. Grønhøj A., Bech-Larsen T., Chan K., and Tsang L., (2013) "Using theory of planned behaviour to predict healthy eating among Danish adolescents," Health Education, vol. 113, pp. 4-17.

7. Hosseini Z., Aghamolaei T., GharlipourGharghani Z. Z, and Ghanbarnejad A., (2015) "Effect of educational interventions based on the theory of planned behaviour to promote breakfast consumption behaviour in students," HMJ, vol. 19, pp. 31-39.

8. Hoyland A., Dye L., and Lawton C. L., (2009) "A systematic review of the effect of breakfast on the cognitive performance of children and school-going children," Nutrition Research Reviews, vol. 22, no. 2, pp. 220-243.

9. I am. Sharma, (1998) "Trends in the intake of ready-to-eat food among urban school children in India," SCN News, vol. 16, p. 21.

10. India Health Research Council, (2014) Adolescent Nutrition Survey in India, India Health Research Council, New Delhi, India.

11. Joseph N., Nelliyanil M., Sharada Rai R. B., Kotian S. M., Ghosh T., and Singh M., (2015) "Fast food consumption pattern and its association with overweight among high school boys in Mangalore city of southern India," Journal of Clinical and Diagnostic Research: JCDR, vol. 9, no. 5, pp. 1-10.

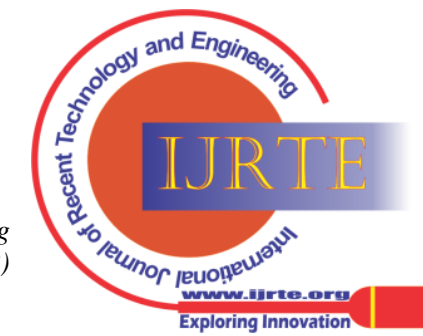


12. Kar B. R., Rao S. L., and Chandramouli B. A., (2008) "Cognitive development in children with chronic protein-energy malnutrition," Behavioral and Brain Functions, vol. 4, no. 1, p. 31.

13. Kar S. and Khandelwal B., (2018) "Fast foods and physical inactivity are risk factors for obesity and hypertension among adolescent school children in east district of Sikkim, India," Journal of Natural Science, Biology and Medicine, vol. 6, no. 2, p. 356.

14. Khalaj M., (2006) "Health education effects on nutritional behaviour modification in primary school students," Journal of Shahrekord University of Medical Sciences, vol. 8, pp. 41-49.

15. Khorasani E. C., Peyman N., and Moghzi M., (2017) “Application of the Theory of Planned Behavior to predict low-nutrient junk food consumption among male students," Journal of Health Sciences and Technology, vol. 1, no. 2, pp. 75-79.

16. Lloyd L. J., Langley-Evans S. C., and McMullen S., (2012) "Childhood obesity and risk of the adult metabolic syndrome: a systematic review," International Journal of Obesity, vol. 36, no. 1, pp. 1-11.

17. Mallick N., Ray S., and Mukhopadhyay S., (2014) "Eating behaviours and body weight concerns among adolescent girls," Advances in Public Health, vol. 2014, pp. 1-8.

18. Ministry of Health and Population; (2011) Population Division, India Population Report, Ministry of Health and Population; Population Division, Kathmandu, India.

19. Nazari A., Jalili Z., and Tavakoli R., (2016) "The evaluation of effects of educational intervention based on planned behaviour theory on reduction of unhealthy snack consumption among Kermanshah elementary school students, 2015-2016," International Journal of Research in Medical Sciences, vol. 5, pp. 67-71.

20. Niemeier H. M., Raynor H. A., Lloyd-Richardson E. E., Rogers M. L., and Wing R. R., (2006) "Fast food consumption and breakfast skipping: predictors of weight gain from adolescence to adulthood in a nationally representative sample," Journal of Adolescent Health, vol. 39, no. 6, pp. 842-849.

21. Nixon H. and Doud L., (2011) "Do fast food restaurants cluster around high schools? a geospatial analysis of the proximity of fastfood restaurants to high schools and the connection to childhood obesity rates," Journal of Agriculture, Food Systems, and Community Development, vol. 2, pp. 181-194.

22. Northstone K., Joinson C., Emmett P., Ness A., and Paus T., (2012) "Are dietary patterns in childhood associated with IQ at 8 years of age? A population-based cohort study," Journal of Epidemiology and Community Health, vol. 66, no. 7, pp. 624-628.

23. P'eneau S., Galan P., Jeandel C. et al., (2011) "Fruit and vegetable intake and cognitive function in the SU.VI.MAX 2 prospective study," 8e American Journal of Clinical Nutrition, vol. 94, no. 5, pp. 1295-1303.

24. Popkin B. M. and Doak C. M., (1998) "The obesity epidemic is a worldwide phenomenon," Nutrition Reviews, vol. 56, no. 4, pp. 106114.

25. Pour-Abdollahi P., Zarate M., Razavieh S. V., Dastgiri S., Ghaem Maghami S. J., and Fathi Azar E., (2004) "The effect of nutrition education on the knowledge and practice of elementary school children regarding junk food intake," Journal of Zanjan University of Medical Sciences, vol. 13, pp. 13-20.

26. Rayner G., Hawkes C., Lang T., and Bello W., (2006) "Trade liberalization and the diet transition: a public health response," Health Promotion International, vol. 21, no. suppl_1, pp. 67-74.

27. Rising India, Changing Food Culture, Rising India, Kathmandu, India.

28. Sahoo K., Sahoo B., Choudhury A. K., Sofi N. Y., Kumar R., and Bhadoria A. S., (2015) "Childhood obesity: causes and consequences," Journal of Family Medicine and Primary Care, vol. 4, no. 2, p. 187.

29. Sapkota S. D. and Neupane S., (2017) "Junk food consumption among secondary level students, Chitwan," Journal of India Paediatric Society, vol. 37, no. 2, pp. 147-152.

30. Seo H. S., Lee S. K., and Nam S., (2011) "Factors influencing fast food consumption behaviours of middle-school students in Seoul: an application of the theory of planned behaviours," Nutrition Research and Practice, vol. 5, no. 2, pp. 169-178.

31. Shah T., Purohit G., Nair S. P., Patel B., Rawal Y., and Shah R. M., (2014) "Assessment of obesity, overweight and its association with and Diagnostic Research: JCDR, vol. 8, no. 5, pp. CC05-CC07, 2014.

32. Shahanjarini A. K., Shojaezadeh D., Majdzadeh R., Rashidian A., and Omidvar N., (2009) "Application of an integrative approach to identify determinants of junk food consumption among female the fast-food consumption in medical students," Journal of Clinical

adolescents," Journal of Health Sciences and Technology, vol. 4, no. 2, pp. 61-70.

33. Shetty P., (2013) "Nutrition transition and its health outcomes," $8 e$ Indian Journal of Pediatrics, vol. 80, no. S1, pp. 21-27.

34. Stuckler D., McKee M., Ebrahim S., and Basu S., (2012) "Manufacturing epidemics: the role of global producers in increased consumption of unhealthy commodities including processed foods, alcohol, and tobacco," PLoS Med, vol. 9, no. 6, Article ID e1001235.

35. Thow A. M. and Hawkes C., (2009) "The implications of trade liberalization for diet and health: a case study from Central America,' Globalization and Health, vol. 5, no. 1, p. 5.

36. Venables W. N. and Smith D. M., (2008) 8e R Development Core Team. An Introduction to $R$, $\mathrm{R}$ Foundation for Statistic, Vienna, Austria.

37. Von Stumm S., (2012) "You are what you eat? meal type, socioeconomic status and cognitive ability in childhood," Intelligence, vol. 40, no. 6, pp. 576-583.

38. World Health Organization, (2016) 8e Stronger Focus on Adolescent Health, World Health Organization, Geneva, Switzerland.

39. World Health Organization, (2018) Maternal, Newborn, Child and Adolescent Health, World Health Organization, Geneva, Switzerland.

40. World Health Organization, (2020) Tenfold Increase in Childhood and Adolescent Obesity in Four Decades, World Health Organization, Geneva, Switzerland.

\section{AUTHORS PROFILE}

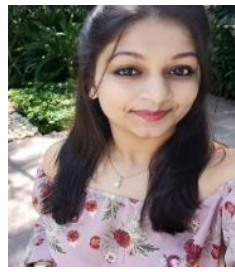

Ms. Sakshi Mehta currently pursuing $\mathrm{PhD}$ from Department of Home Science (Foods \& Nutrition) IIS Deemed to be a University, Jaipur (Rajasthan) She has keen interest in field of Nutrition and Dietetics. She has been actively working in the field Foods \& Nutrition with specialization on pediatric nutrition and health of school children's. She is a life member of Indian Dietetic Association. She has also authored a manual 'Eat Right, Be Bright!'- A planning guide for school health with ISBN No. 978-93-9084621-4. During her research tenure she has presented a number of papers in referred Journals and participated in a range of forums at national and international conferences.

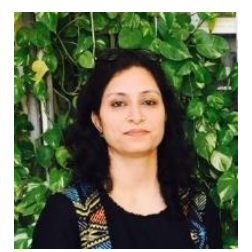

Dr. Swati Vyas is working since 2006 at the designation of Associate Professor in Department of Home Science, Foods and Nutrition in Esteemed University of Rajasthan, IIS Deemed to be a University, Jaipur (Rajasthan). She has been actively associated with field of Academics and Research. She has vast Research experience with approximately thirty research papers published in journals of repute one $\mathrm{PhD}$ awarded and others ongoing. Her research thrusts areas are Public Nutrition, Nutrition Education, Food Product Development, Clinical Nutrition, Maternal and Child Nutrition, NonCommunicable Diseases. In addition to her academic and research career, Dr Vyas held several administrative positions in IIS Deemed to be a University, Jaipur.

Published By:

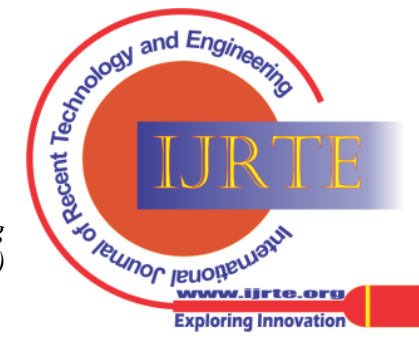

